\title{
A BIOPHYSIOCHEMICAL ANALYSIS OF SETTLED LIVESTOCK AND POULTRY HOUSING DUSTS
}

\author{
${ }^{1,2}$ Carresse Gerald, ${ }^{1}$ Christi McPherson, \\ ${ }^{1}$ Tha'Mes McDaniel, ${ }^{3}$ Zhigang Xu, ${ }^{4}$ Bryce Holmes, \\ ${ }^{5}$ Leonard Williams, ${ }^{6}$ Niki Whitley and ${ }^{1}$ Jenora Turner Waterman \\ ${ }^{1}$ Department of Animal Sciences, \\ ${ }^{2}$ Department of Energy and Environmental Systems, \\ ${ }^{3}$ Department of Mechanical Engineering, \\ ${ }^{4}$ Department of Natural Resources and Environmental Design, \\ School of Agriculture and Environmental Sciences Analytical Services Laboratory, \\ ${ }^{5}$ Center of Excellence in Post-Harvest Technologies, \\ ${ }^{6}$ The Cooperative Extension Program, \\ North Carolina Agricultural and Technical State University, Greensboro, NC, USA
}

Received 2013-09-20; Revised 2014-01-16; Accepted 2014-01-16

\begin{abstract}
The levels and composition of agricultural dusts are influenced by animal species, production strategy, housing type and ventilation efficiency. Agricultural dust within animal houses is complex and consists of feed particles, microbes and their products, dander, fecal matter, gases, metals and other organic and inorganic components. Livestock and poultry production facilities may be categorized as confinement, semi-confinement or pasturebased. Characterization of animal husbandry building dust will provide insight into understanding exposures experienced by animals, workers and farm visitors. The goal was to characterize biophysiochemical features of livestock dusts from swine, small ruminant, equine, poultry and cattle husbandry units. Settled dust samples were collected from livestock and poultry housing units at the University Farm and other livestock farms across the state. Morphological features were determined by electron microscopy and gravimetry. Biochemical evaluation consisted of $\mathrm{pH}$ determination and trace metal detection via mass spectrometry. Biological assessment centered on bacterial characterization via selective media, DNA analysis and endotoxin quantitation. Morphological analyses revealed higher levels of respirable and thoracic particles in poultry, swine, small ruminant and equine units compared to the dairy unit $(\mathrm{p}<0.01)$. Dusts were slightly acidic with the exception of the NCAT small ruminant unit $(\mathrm{p}<0.05)$. Dust endotoxin levels were consistent and bacterial species detected include Listeria and Escherichia coli. These findings suggest animal husbandry buildings harbor higher levels of smaller respirable and thoracic dust particles compared to inhalable particles. This information may be helpful in understanding dust exposures experienced by animals, farmers and agricultural workers.
\end{abstract}

Keywords: Agriculture, Animal Housing, Bacterial Identification, Organic Dust, Particle Characterization, Settled Dust

\section{INTRODUCTION}

Animal agriculture is a multi-billion dollar global industry and meat products supply an ever increasing demand; the No. 1 consumed meat in the world is pork
(36\%), followed by poultry (33\%) and beef (24\%) (FOA, 2012). Due to the high demand for meat, some livestock production operations shifted to efficient confinement systems that allow faster productionin environmentally controlled buildings that safeguard against temperature 1601 East Market Street, Greensboro, North Carolina 27411, USA, Tel: 336-285-4815, Fax: 336-334-7288 
extremes, predatorsand disease incidence. However, a consequence of confinement production is reduction in air quality associated with accumulation of dust and gases. Semi-confinement production facilities usually have indoor and outdoor components and thus, dust is typically less concentrated compared to the confinement facilities.

Animals, farmers and workers within animal confinement facilities may be exposed to higher levels of inorganic substances, feed grains, organic dusts, microbes and their products, gases and chemicals (e.g., pesticides, disinfectants) compared to outdoor operations. Grain dusts contribute heavily to agricultural dust composition among swine, dairy and poultry farms (Donham et al., 2002; Lee et al., 2006). It is well established that occupational exposure to agricultural dusts is a risk factor for respiratory dysfunction in swine and poultry facility workers chronically exposed to dust consisting of feed particles, bacterial endotoxin, gases and other components (O'Shaughnessy et al., 2010; Viegas et al., 2013). Bioaerosols, volatile compounds, gases and inorganic compounds including alcohols, aromatics and nitrogenrelated contribute to animal production dust complexity (Plummer et al., 2009; Chmielowiec-Korzeniowska, 2009; Hamon et al., 2012). Simultaneous exposure to poultry production dust particulates and ammonia resulted in a synergistic decline in pulmonary function in workers (Donham et al., 2002).

Although it is well accepted that exposure to animal housing dust is associated with respiratory symptoms in workers (May et al., 2012; Mitloehner and Calvo, 2008), reports summarizing the respiratory effects associated with inhalation of agricultural dusts linked to specific dust components are limited. Thus, it is intriguing to characterize dusts from animal husbandry units to gain a better understanding of inhalation exposures and risks. To begin assessing exposures, settled dust samples were collected from raised surfaces at the swine and poultry confinement units and the dairy, small ruminant and equine semi-confinement buildings at the North Carolina $\mathrm{A}$ and T State University (NCAT) Farm and five other farms across the state of North Carolina. The purposes for collecting the samples were to determine the chemical, physical and microbial composition of settled dusts that could affect respiratory health by inhalation.

\section{MATERIALS AND METHODS}

\subsection{Approach}

The analyses were primarily conducted on dusts collected from the livestock units at the NCAT Farm (Table 1). Samples were also collected from two small ruminant, two horse and one beef cattle farms across the state. Qualitative and quantitative evaluations were conducted to identify physical, chemical and microbial constituents of the dust.

The first analyses were designed to characterize physical components of the dust. This was accomplished by using Scanning Electron Microscopy (SEM) and simple gravimetric analysis to ascertain particle size and morphology. The second set of analyses included chemical analyses including evaluation of element levels and $\mathrm{pH}$ determinations. Finally, microbiological characterization was performed utilizing endotoxin quantification, identification via growth on selective media, dust DNA quantitation and gene analysis by Polymerase Chain Reaction (PCR).

The aforementioned characterization strategy for dust samples was selected based on housing and species type, biological components of the dust (i.e., bacteria important to respiratory disease or foodborne illness) and chemicals used in the upkeep of the facilities. Therefore, it was imperative to observe the various dimensions of the dust to determine the size of the particles in relation to where they may deposit along the respiratory tract. Chemical analyses were conducted to characterize dust from different species/unit settings. Animals housed in semi-confinement facilities can track soil from the pasture inside and elements from soil can become aerosolized and contribute to dust composition. Finally, we conducted microbiological analyses to provide bacterial profiles for dust samples.

\subsection{Analytic Methods}

\subsubsection{Dust Sampling and Mixture Preparation}

Settled dust was obtained from raised surfaces at the North Carolina Agricultural and Technical State University swine, poultry, equine, dairy and small ruminant (caprine and ovine) units. Samples were also collected from five other farms across North Carolina: 1Equine, 2-Caprine, 3-Bovine (beef cattle) and Equine, 4Bovine (beef cattle), 5-Caprine and Ovine. For sampling, approximately 10-15 grams of settled dust on fixtures was brushed into a ziptop plastic bag using a clean cosmetic brush and transported immediately to the laboratory for further processing as previously described with a few modifications (Wyatt et al., 2008). Briefly, a 1:10 (w/v) Dust Mixture (DM) was prepared by combining 0.5 grams of dust with $5 \mathrm{~mL}$ of Hank's Buffered Saline Solution (HBSS). The mixture was vortexed for one minute and left to stand at room temperature for one hour. The DM was used for $\mathrm{pH}$ readings and gravimetric analysis as detailed below. Dust samples were collected from the same locations within each building several times over a two year period (for NCAT units only). 
Table 1. Selective media for bacterial identification

\begin{tabular}{lll}
\hline Medium symbol & Medium name & Bacterial selection \\
\hline Centrimide $^{\mathrm{a}}$ & Remel Centrimide & Pseudomonas \\
MYP $^{\mathrm{a}}$ & Mannitol egg yolk polymixin & Bacillus \\
TSI $^{\mathrm{a}}$ & Triple Sugar Iron & E. coli, Pseudomonas, Salmonella \\
Oxford $^{\mathrm{b}}$ & Oxford medium base & Listeria \\
$\mathrm{SM}^{\mathrm{a}}$ & Sorbitol MacConkey & E. coli \\
$\mathrm{XLD}^{\mathrm{b}}$ & Xylose Lactone Deoxycholate & Salmonella \\
$\mathrm{RC}^{\mathrm{a}}$ & Oxoid Reinforced Clostridial & Clostridium \\
BP $^{\mathrm{a}}$ & EMD Millipore Baird Parker & Staphylococcus \\
TSA $^{\mathrm{a}}$ & Tryptic Soy agar & Most grow \\
\hline
\end{tabular}

${ }^{\mathrm{a}}$ ThermoFisher; ${ }^{\mathrm{b}} \mathrm{BD}$ Biosciences

\subsection{2. pH Altering Capacity}

To analyze the $\mathrm{pH}$ of animal housing DM, two methods were performed: Neutral litmus paper testing and $\mathrm{pH}$ meter readings. Prior to reading $\mathrm{pH}$, the $\mathrm{DM}$ samples were inverted and vortexed to mix particles.

\subsubsection{Gravimetric Analysis}

To investigate dust particle size, gravimetric analysis was performed using a modified method of Lioy et al. (2002). The P2 and P5 filter papers (Thermo Fisher Scientific, Rockford, IL) were selected to study thoracic and respirable particles; P2 has particle retention of 1-5 $\mu \mathrm{m}$ and P5 has particle retention of 5-10 $\mu \mathrm{m}$. Briefly, the DM samples were separately passed through P2 and P5 filters. Particle retention was estimated from average pre- and postfilter weights. Each dust sample was analyzed at least three times for all units.

\subsubsection{SEM and Energy Dispersive X-Ray Spectroscopy (EDS)}

To analyze dust particulate size, procedures similar to Lioy et al. (2002) were used. For SEM analysis, portions of the dust were placed on conductive carbon tape and a Hitachi SU8000 Field Emission Scanning Electron Microscope (Hitachi High Technologies America, Dallas, TX) was used to capture images. Particle size estimation was completed using the Quartz X-One software. X-ray imaging was performed for elemental analysis (energy dispersive technology) on each dust sample. Two or three SEM images were captured for each sample.

\subsubsection{Trace Element Analysis}

Samples underwent a nitric acid digestion prior to analysis via Inductively Coupled Plasma-Optical Emission Spectrometry (ICP-OES). Nitric acid (5 mL) was added to $0.25 \mathrm{~g}$ of dust from each agricultural unit in a beaker $(250 \mathrm{~mL})$. To obtain a consistent reflux, a watch glass was used to cover the mouth of the beaker. Nitric acid $(5 \mathrm{~mL})$ was added continuously until the solid substance was dissolved; totaling approximately 20-30 $\mathrm{mL}$ of nitric acid depending on dust consistency. This continued until the liquid was a clear yellow color. Sample volumes were brought to $50 \mathrm{~mL}$ final volume with distilled water and filtered using \#42-Whatman filter paper. For ICP-OES analysis, standards containing the following elements were used: Aluminum, calcium, chromium, iron, potassium, manganese, magnesium, sodium, phosphorus, silicon, zinc, cadmium, copper, nickel and lead. Varian 710ES ICP-OES was used to analyze samples using a procedure adapted from EPA Method 3050B Acid digestion of sediments, sludges and soils.

\subsubsection{Endotoxin Assay}

To quantitate endotoxin levels in dust samples, the Pierce LAL Chromogenic Endotoxin Quantitation assay (Thermo Fisher Scientific, Rockford, IL) was used according to manufacturer's instructions. Readings were performed three times using a micro plate reader at $410 \mathrm{~nm}$.

\subsubsection{Biochemical Identification of Dustmicrobiomes}

Animal units at the NCAT Farm were swabbed using a sterile cotton swab and placed in $1 \%$ peptone water for transport. Swabs were streaked onto various selective agar plates (Table 2) and cultured at $37^{\circ} \mathrm{C}$ overnight.

\subsubsection{Microbial DNA Isolation and $16 S$ Ribosomal Gene Analysis}

Evaluation of the $16 \mathrm{~S}$ ribosomal DNA gene, the genomic sequence that encodes the $16 \mathrm{~S}$ portion of 
prokaryotic ribosomes and is thus present in all bacterial species, is an established approach for detection and identification of bacterial species (Ege et al., 2012; Kumari et al., 2013). For bacterial detection and identification, DNA was isolated from dust samples (0.1$0.5 \mathrm{~g}$ ) using the Power Soil DNA isolation kit (Mo Bio, Carlsbad, CA) according to manufacturer instructions. Following DNA quantitation, 16S rDNA gene amplification was performed via Polymerase Chain Reaction (PCR) with primer sets obtained from published reports (Table 3). DNA (100 ng) was combined with forward and reverse primers $(0.2 \mu \mathrm{M}$ each), 2X Go Taq Green (Promega, Madison, WI) and nuclease-free water was added to bring the reaction up to $25 \mu \mathrm{L}$. Samples were amplified using an iCycler thermal cycler (Bio-Rad, Hercules, CA) using a hot start $\left(94^{\circ} \mathrm{C}, 1 \mathrm{~min}\right)$, followed by 35 cycles of denaturation $\left(94^{\circ} \mathrm{C}, 30 \mathrm{sec}\right.$ ), annealing (Table 3 for annealing temperatures, Tm; $30 \mathrm{sec}$ ) and elongation $\left(72^{\circ} \mathrm{C}, 7 \mathrm{~min}\right)$. PCR products were visualized by agarose gel electrophoresis, ethidium bromide staining and photo documentation.

Table 2. North Carolina A and T State University Farm animal husbandry facilities.

\begin{tabular}{|c|c|c|c|c|c|c|c|}
\hline & $\begin{array}{l}\text { Facility } \\
\text { Type }\end{array}$ & $\begin{array}{l}\text { Year } \\
\text { Built }\end{array}$ & $\begin{array}{l}\text { Cleaning } \\
\text { Regimen }^{\mathrm{a}}\end{array}$ & $\begin{array}{l}\text { Animal } \\
\text { Breed/Type }\end{array}$ & $\begin{array}{l}\text { Animal } \\
\text { No. }\end{array}$ & $\begin{array}{l}\text { Feed } \\
\text { Type }\end{array}$ & Bedding \\
\hline Poultry & $\mathrm{C}$ & 2004 & PW & $\begin{array}{l}\text { Broilers Layers } \\
\text { Heritage birds }\end{array}$ & $\begin{array}{l}4000 \\
400 \\
50\end{array}$ & Pellet & $\begin{array}{l}\text { Wood } \\
\text { shavings }\end{array}$ \\
\hline Swine & $\mathrm{C}$ & $1983 / 2006$ & PW & Commercial breeds & 150 & Pellet & Slatted floors \\
\hline Equine & $\mathrm{SC}$ & 2005 & GPB & $\begin{array}{l}\text { Arabian }^{\mathrm{c}} \\
\text { Quarter Horse }\end{array}$ & 3 & $\begin{array}{l}\text { Pasture, } \\
\text { Hay, Mixed } \\
\text { grain feed }\end{array}$ & $\begin{array}{l}\text { Wood } \\
\text { shavings }\end{array}$ \\
\hline $\begin{array}{l}\text { Small } \\
\text { Ruminant }\end{array}$ & $\mathrm{SC}$ & 1998 & GPB, Broom & $\begin{array}{l}\text { Boer goats } \\
\text { Hair sheep }\end{array}$ & $\begin{array}{l}50 \\
20\end{array}$ & $\begin{array}{l}\text { Pasture, } \\
\text { Pellet, Hay }\end{array}$ & $\begin{array}{l}\text { Wood } \\
\text { shavings }\end{array}$ \\
\hline Dairy & $\mathrm{SC}$ & 2006 & $\mathrm{PW}^{\mathrm{b}}$ & Holstein, Jersey & $45^{\mathrm{d}}$ & $\begin{array}{l}\text { Pasture Pellet, } \\
\text { Corn silage }\end{array}$ & $\begin{array}{l}\text { Canvas mat and } \\
\text { wood shavings }\end{array}$ \\
\hline
\end{tabular}

${ }^{\mathrm{a}}$ Cleaning practices, generally broom/GPB used daily; bedding changed monthly or as needed when changing animal groups; ${ }^{\mathrm{b}} \mathrm{Twice}$ daily, especially after milking; ${ }^{\mathrm{C}}$ Mare, two geldings; ${ }^{\mathrm{d}}$ Milking, dry, heifers; C, Confinement; SC, Semi-Confinement; PW, Pressure Washed; GPB, Gas Powered Blower

Table 3. Primers used for identification of bacteria via PCR

\begin{tabular}{|c|c|c|c|c|c|}
\hline Organism & Primer name & Sequence & $\mathrm{Tm}$ & Product Size, bp & Reference \\
\hline \multirow[t]{2}{*}{ E. coli } & Ecoli670-F & 5'-ACCTGCGTTGCGTAAATA-3' & $58^{\circ} \mathrm{C}$ & 670 & McDaniels et al. (1996) \\
\hline & Ecoli670-R & 3'-GGGCGGGAGAAGTTGATG-5' & & & \\
\hline \multirow[t]{2}{*}{ Listeria } & LM404-F & 5'-ATCATCGACGGCAACCTCGGAGAC-3' & $68^{\circ} \mathrm{C}$ & 404 & Wu et al. (2004) \\
\hline & LM404-R & 3'-CACCATTCCCAAGCTAAACCAGTGC-5' & & & \\
\hline \multirow[t]{2}{*}{ Salmonella spp. } & Sal284-F & 5'-GTGAAATTATCGCCACGTTCGGGCAA-3' & $64^{\circ} \mathrm{C}$ & 284 & Rahn et al. (1992) \\
\hline & Sal284-R & 3'-TCATCGCACCGTCAAAGGAACC-5' & & & \\
\hline \multirow[t]{2}{*}{ Bacillus } & $8 \mathrm{~F}$ & 5'-AGTTGATCCTGGCTCAG-3' & $52^{\circ} \mathrm{C}$ & 1554 & Sacchi et al. (2002) \\
\hline & $1429 \mathrm{R}$ & 3'-ACCTTGTTACGACTT-5' & & & \\
\hline \multirow[t]{2}{*}{ Clostridium } & 16SUNI-L & 5'-AGAGTTTGATCATGGCTCAG-3' & $54^{\circ} \mathrm{C}$ & 1500 & Sasaki et al. (2001) \\
\hline & UNI16S-R & 3'-AAGGAGGTGATCCAGCCGCA-5' & & & \\
\hline \multirow[t]{2}{*}{ Actinomycetes } & F243 & 5'-GGA TGA GCC CGC GGC CTA-3' & $72^{\circ} \mathrm{C}$ & 1176 & Heuer et al. (1997) \\
\hline & $\mathrm{R} 1378$ & 3'-CGG TGT ACA AGG CCC GGG AAC G-5' & & & \\
\hline \multirow[t]{2}{*}{ Staphylococcus } & Seb-1(fwd) & 5'-TCG CAT CAA ACT GAC AAA CG-3' & $55^{\circ} \mathrm{C}$ & 477 & Becker et al. (1998) \\
\hline & Seb-4(rev) & 3'GCA GGT ACT CTA TAA GTG CCT GC-5' & & & \\
\hline \multirow[t]{2}{*}{ Pseudomonas } & Ps-for & 5'-GGTCTGAGAGGATGATCAGT-3' & $55^{\circ} \mathrm{C}$ & 1007 & Widmer et al. (1998) \\
\hline & Ps-rev & 3'-TTAGCTCCACCTCGCGGC-5' & & & \\
\hline
\end{tabular}

bp, base pair 


\subsubsection{Statistical Analysis}

Analyses were performed using Prism version 5.0. (Graph Pad Software, Inc., San Diego, CA) using Analysis of Variance (ANOVA). Differences between means were considered statistically significant when $P$ values were less than 0.05.Bonferroni or Dunnett's posttest corrections were utilized to evaluate differences among means. All experiments were performed at least three times unless otherwise noted and values are reported as means \pm Standard Error $(\mathrm{SE})$ or Standard Deviation (SD).

\section{RESULTS}

Physically, all dusts were variations of brown in color. The poultry unit dust was fluffy and the lightest in color. The NCAT dairy dust was grainy/pebbled and darkest of the dusts. Swine unit dust was fine in consistency while equine dusts were hard in texture and light in color. Small ruminant dusts were less fluffy than poultry unit dust. Overall, the cattle dusts were coarser than the other dusts.

\subsection{Animal Husbandry Dust Particle Sizes}

Through gravimetric analysis, smaller particles in the size range of 1-5 $\mu \mathrm{m}$ were detected for each NCAT unit based on five-fold $(\mathrm{p}<0.001)$ higher retention levels on P2 filters compared to P5 filters (Fig. 1). This indicates more particles $\leq 5 \mu \mathrm{m}$ passed through the P5 filter. These data were consistent with particles measurements determined via SEM (Fig. 2). The largest particle sizes were detected in dairy building dust, for which the average particle size was $37.86 \mu \mathrm{m}$. The NCAT diary unit also had the greatest particle size range, 5.11-154.5 $\mu \mathrm{m}$, while the poultry unit had the some of the smallest particles with an average size of $12.5 \mu \mathrm{m}$ and a narrow particle size range of 5.23 - $26.93 \mu \mathrm{m}$ (Fig. 3, Table 4). By way of simple gravimetric analysis and SEM analysis it was determined that animal housing buildings contained higher levels of respirable and thoracic particles $(1-5 \mu \mathrm{m})$ than large inhalable particles $(<30$ $\mu \mathrm{m})$ based on the American Conference of Industrial Hygienists (ACGIH) classification (WHO, 1999). Table 4 provides a summary of particle size averages and ranges for dusts collected from NCAT Farm.

\subsection{Dust pH}

With the exception of the alkaline small ruminant (NCAT) dust suspension ( $\mathrm{pH}$ of 7.9), the $\mathrm{pH}$ of aqueous suspensions of all dust samples were acidic $($ Dairy $=6.67$, Swine $=6.84$, Poultry $=6.78$, Equine $=$ 6.93) compared to the basic HBSS control (Fig. 4). There was no difference between $\mathrm{pH}$ measurements collected by $\mathrm{pH}$ meter compared to the litmus paper test (results not shown).

\subsection{Element Concentrations Determined by SEM/EDS and ICP-OES}

As shown in Table 5 and 6 respectively, most of the elements detected in NCAT dusts were in the ppm $(\mu \mathrm{g} / \mathrm{g})$ concentration range. Phosphorus and sulfur levels were 510 fold higher in swine unit dust compared to other units.

\subsection{Endotoxin Levels and Bacterial Presence}

Dust endotoxin levels were quantified for all livestock units sampled. The levels ranged between 2.39 Endotoxin Units (EU/ml) (dairy) and $1.64 \mathrm{EU} \mathrm{mL}^{-1}$ (swine) for NCAT animal units and between $2.37 \mathrm{EU}$ $\mathrm{mL}^{-1}$ (5-Caprine and Ovine) and $2.84 \mathrm{EU} \mathrm{mL}^{-1}$ (1Equine) for other farms (Fig. 5). There were no differencesin endotoxin levels among dusts tested.

To identify bacterial species present in NCAT Farm animal housing dusts, selective growth media and PCR analysis were performed. Bacteria of interest included species common to agricultural settings known to be clinically important to food borne and respiratory illnesses. Most of the selective agars were effective at growing bacteria from the various dusts collected from animal husbandry units. As summarized in Table 7, positive bacterial growth corresponds to the detection of Bacillus (MYP); E. coli, Pseudomonas, Salmonella (TSI); Listeria (Oxford); Clostridium (RC) and Staphylococcus (BP). E. coli was also detected on Sorbitol MacConkey media from the swine unit only. Tryptic soy agar, a permissive growth medium, showed growth for all units.

Together with Table 7 and Fig. 6 depicts successful bacterial growth and amplification of the $16 \mathrm{~S}$ ribosomal gene from NCAT Farm dust DNA samples, respectively. Measureable bacterial growth was observed for each of the selective agars with the exception of Centrimide, which exclusively detects Pseudomonas species and XLD, a selective medium for Salmonella species (Table 7). Notably, 16S rDNA from more bacterial species were detected in the swine unit dust compared other units and include Listeria, Clostridium, Bacillus, Pseudomonas, Salmonella, E. coli, Staphylococcus and Actinomycetes (Fig. 6). However, Listeria $16 \mathrm{~S}$ rDNA had the highest levels $(\mathrm{p}<0.01)$ was detected in dusts from all five of the NCAT Farm animal housing buildings (Fig. 6). 
Carresse Gerald et al. / American Journal of Agricultural and Biological Sciences 9 (2): 153-166, 2014

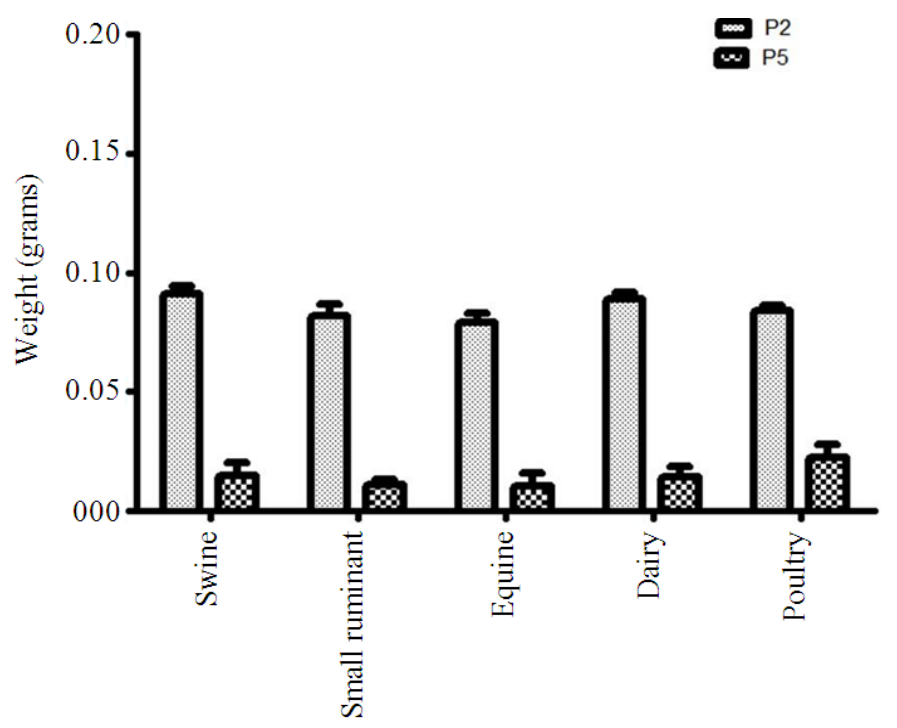

Fig. 1. Gravimetric Analysis of DM from NCAT Agricultural Units. Dust particles were retained on either P2 (1-5 $\mu \mathrm{m}$ retention) or P5 (5-10 $\mu \mathrm{m}$ retention) filter papers. More particles were between 1-5 $\mu \mathrm{m}$ based on higher retention on P2 filters compared to P5 filters; $\mathrm{p}<0.01$. Data are shown as mean \pm SE for three replicates
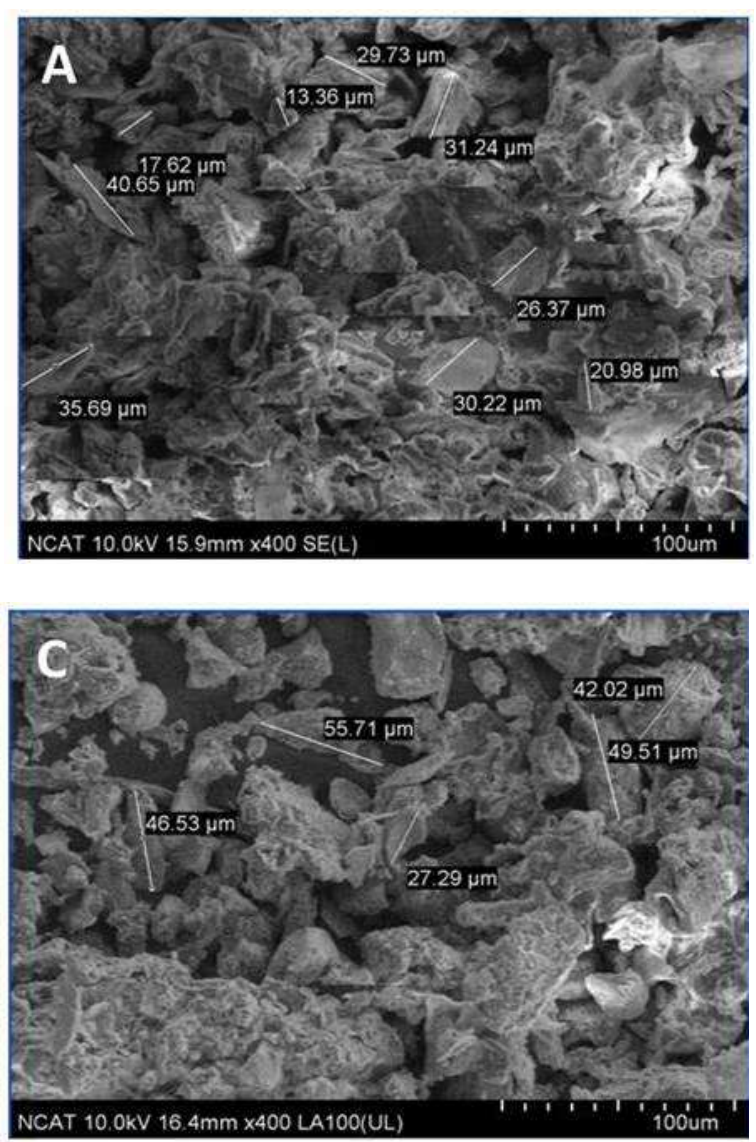
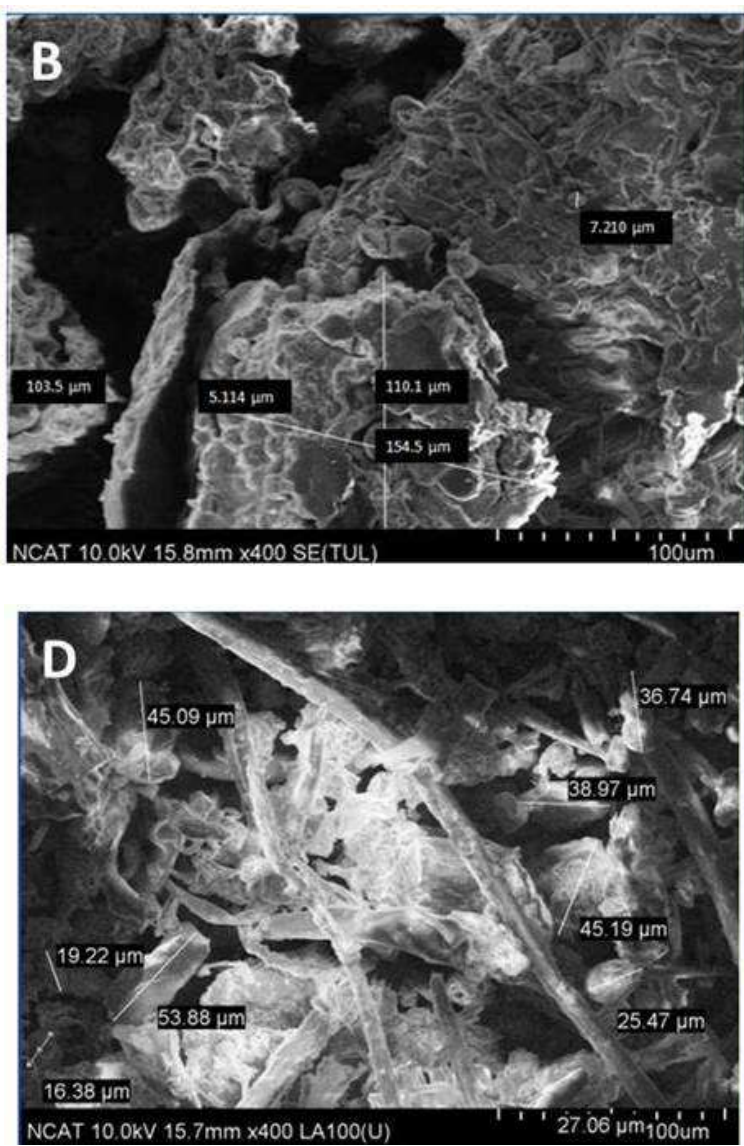


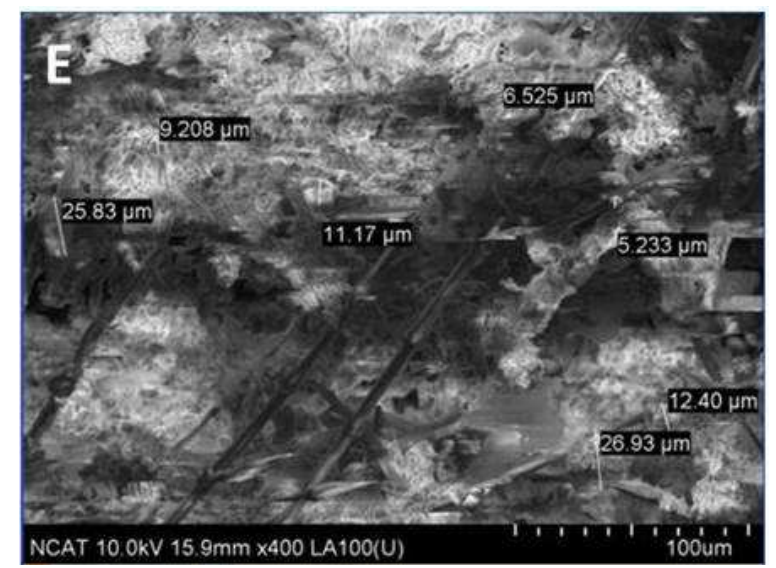

Fig. 2. Scanning electron micrographs of animal husbandry dusts from NCAT Farm. A-Swine, B-dairy, C-equine D-poultry, E-small ruminant. All images are representative of at least two per sample. Magnification $=400 \mathrm{X}$

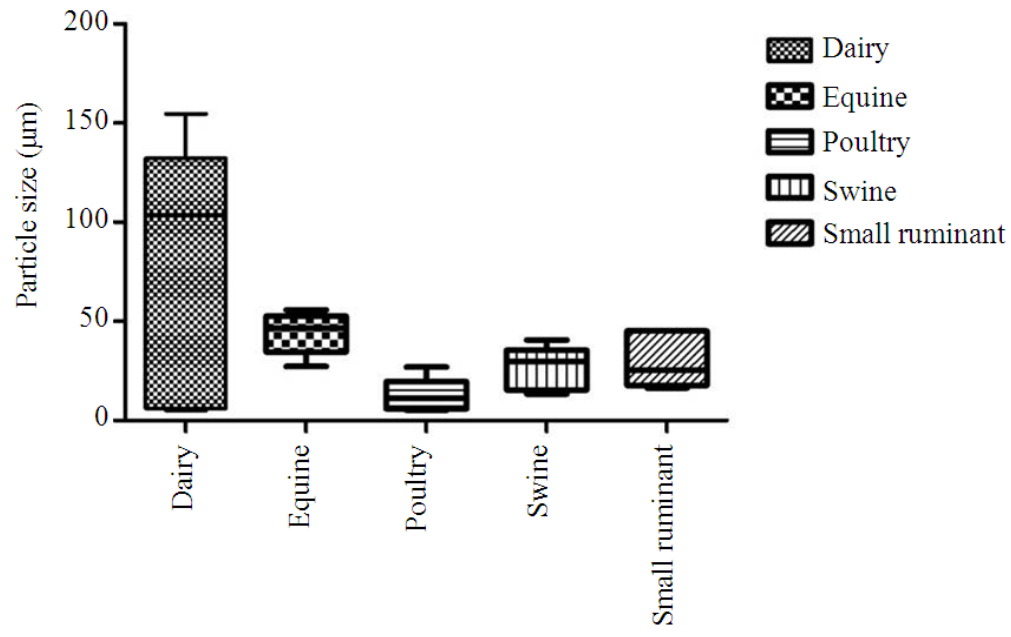

Agriculture units

Fig. 3. Particle size estimation of NCAT animal husbandry dusts by SEM. The dairy unit had higher particles sizes when compared to the poultry unit; $\mathrm{p}<0.05(\mathrm{n}=3)$ using SEM. Data are shown as mean $\pm \mathrm{SE}$ three replicates

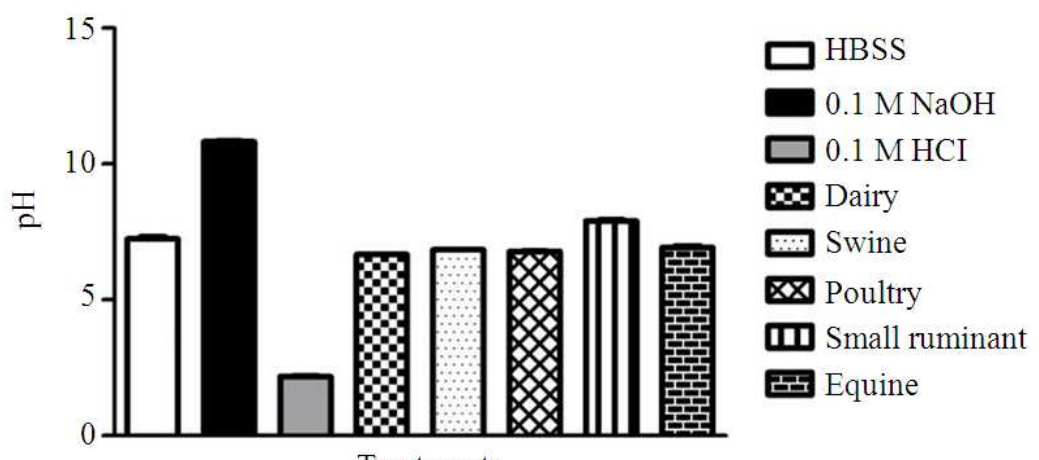

Treatments

(a) 


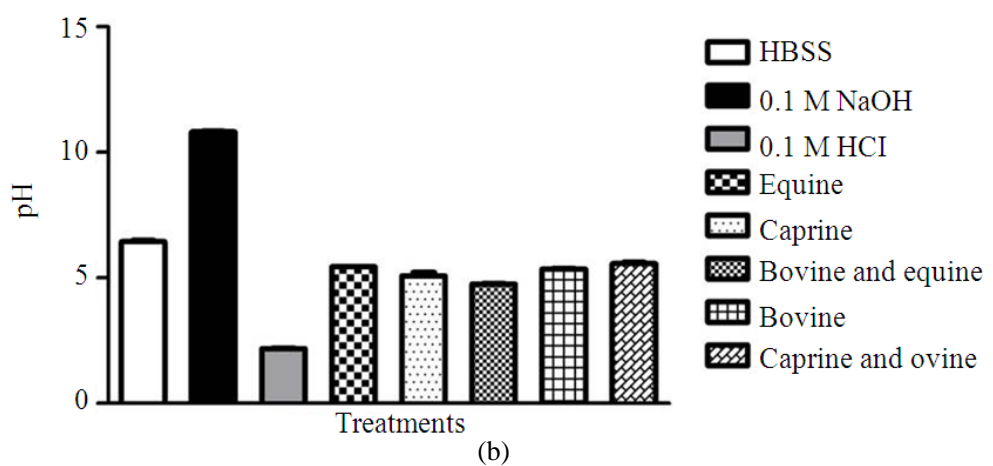

Fig. 4. $\mathrm{pH}$ of settled animal husbandry dusts from NCAT (A) and (B) other farms across North Carolina. HBSS, Hank's buffered saline solution, was the solvent for dusts. $\mathrm{HCl}$, hydrochloric acid and $\mathrm{NaOH}$, sodium hydroxide were acidic and alkaline controls, respectively. Data are shown as mean $\pm \mathrm{SE}$ for three samples each

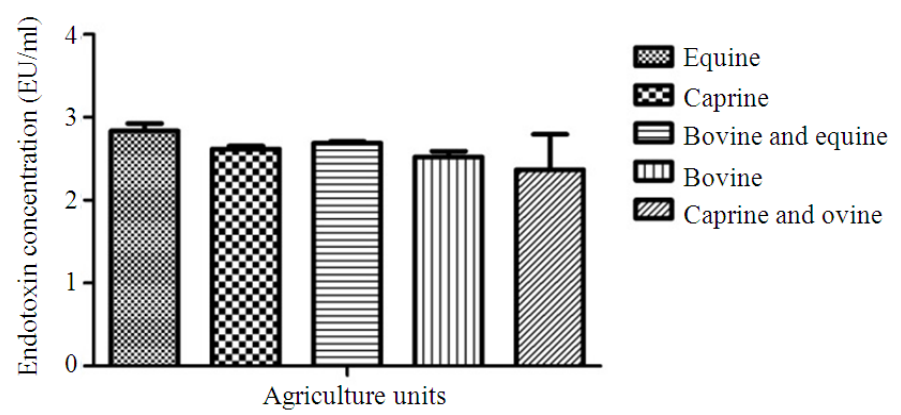

Fig. 5. Endotoxin levels within animal housing units. Data presented as endotoxin units per $\mathrm{ml}$ for $\mathrm{n}=3$ samples per unit. Data are shown as mean $\pm \mathrm{SE}$

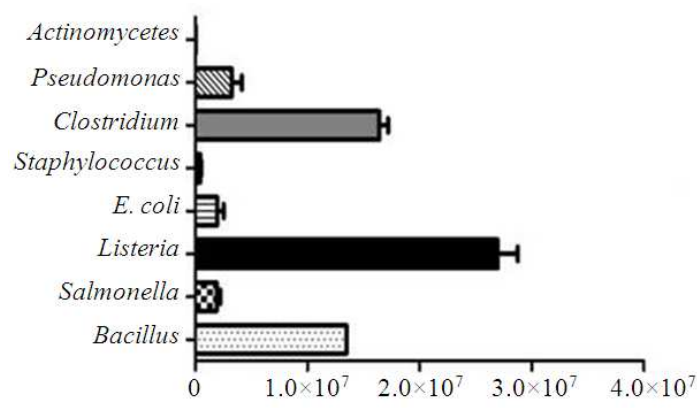

(a)

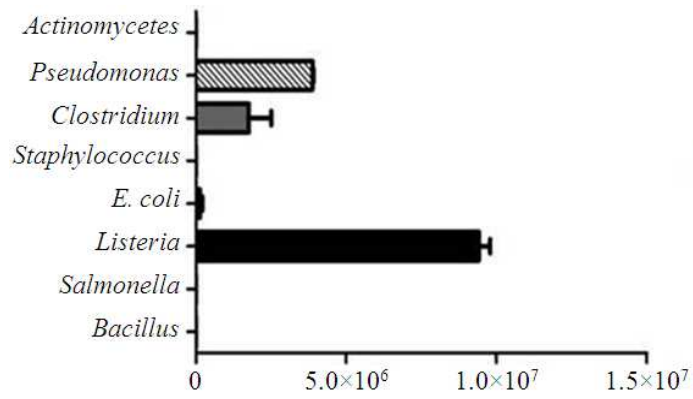

(c)

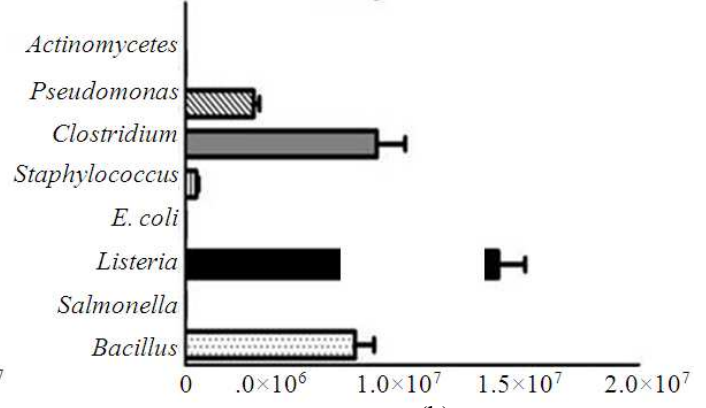

(b)

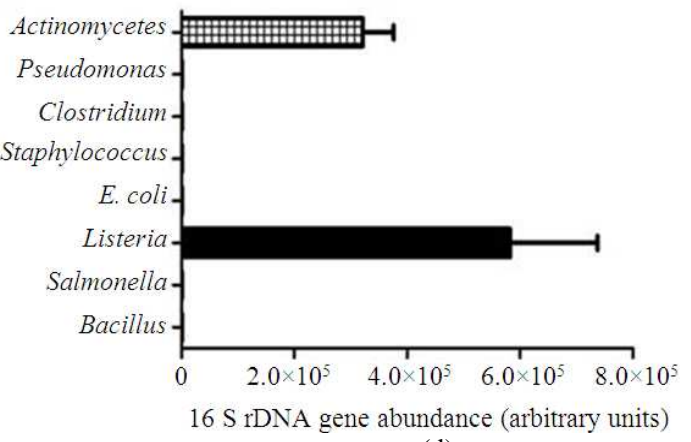

(d) 


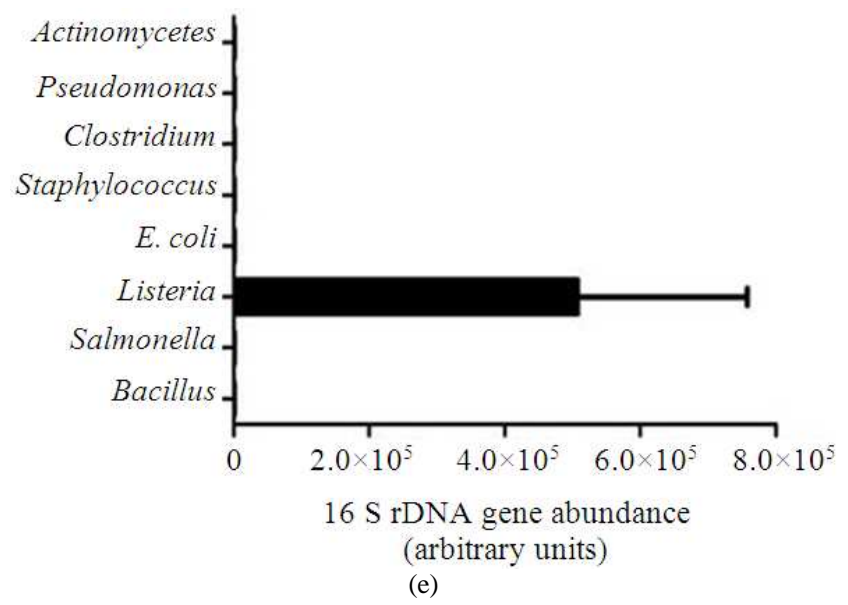

Fig. 6. Detection of bacterial 16S ribosomal DNA gene in dust samples. Bacterial presence in dusts from swine, dairy, small ruminant, equine and poultry units at the NCAT Farm were confirmed by PCR. Data are shown as mean \pm SE $(n=3)(a)$ Swine (b) Dairy (c) Small ruminant (d) Equine (e) Poultry

Table 4. Animal husbandry unit dust particle size estimation by SEM

\begin{tabular}{|c|c|c|c|}
\hline Agriculture Unit & Average particle size & $\begin{array}{l}\text { Particle Size } \\
\text { Range }(\mu \mathrm{m})\end{array}$ & Standard deviation \\
\hline Dairy & 76.10 & $5.11-154.50$ & 66.770 \\
\hline Equine & 44.20 & $27.29-55.71$ & 10.680 \\
\hline Poultry & 12.50 & $5.23-26.93$ & 8.630 \\
\hline Small Ruminant & 30.27 & $16.38-45.19$ & 13.960 \\
\hline Swine & 26.30 & $13.36-40.65$ & 10.900 \\
\hline
\end{tabular}

Table 5. Energy Dispersive X-ray Spectroscopy on Agriculture Dusts collected from the Animal Housing Units at the NCAT Farm

\begin{tabular}{|c|c|c|c|c|c|c|c|c|c|c|c|}
\hline Element $(\mathrm{C} \%)$ & $\mathrm{O}$ & $\mathrm{Na}$ & $\mathrm{Al}$ & $\mathrm{Si}$ & $\mathrm{P}$ & $\mathrm{S}$ & $\mathrm{Cl}$ & $\mathrm{K}$ & $\mathrm{Ca}$ & $\mathrm{Mg}$ & $\mathrm{Fe}$ \\
\hline Poultry & 79.52 & 0.83 & 1.33 & 1.96 & 3.06 & 1.18 & 0.50 & 3.08 & 5.91 & 2.63 & ND \\
\hline Swine & 77.96 & 2.52 & 0.62 & 0.91 & 4.35 & 1.63 & 1.69 & 5.11 & 2.57 & 2.55 & 0.09 \\
\hline Equine & 69.01 & 1.23 & 5.62 & 16.32 & 0.25 & 0.36 & 0.31 & 1.13 & 2.01 & 1.35 & 2.42 \\
\hline Sm.Rum. & 74.13 & 1.09 & 2.87 & 11.47 & 1.01 & 0.60 & 0.80 & 1.96 & 3.33 & 1.56 & 1.19 \\
\hline Dairy & 87.58 & 1.57 & 0.88 & 2.59 & 1.41 & 0.52 & 0.45 & 1.86 & 1.36 & 1.51 & 0.27 \\
\hline
\end{tabular}

ND, not detected; C\%, percent carbon atom; Sm. Rum., small ruminant; Bold, indicates highest concentration of element detected

Table 6. ICP-OES MS analysis of agriculture dusts collected from the NCAT animal houses

\begin{tabular}{lrllrlrlrrrrr}
\hline Element conc./ppm & \multicolumn{1}{c}{$\mathrm{AL}$} & $\mathrm{Ca}$ & $\mathrm{Cr}$ & \multicolumn{1}{c}{$\mathrm{Fe}$} & $\mathrm{K}$ & $\mathrm{Mg}$ & $\mathrm{Mn}$ & $\mathrm{Na}$ & $\mathrm{P}$ & $\mathrm{S}$ & $\mathrm{Si}$ & $\mathrm{Zn}$ \\
\hline Agriculture Unit & & & & & & & & & & & & \\
Poultry & 3.37 & 184.66 & $\mathrm{BDL}$ & 4.50 & 90.20 & 41.87 & 0.60 & 12.39 & 28.98 & 19.77 & 215.04 & 1.49 \\
Swine & 9.67 & 280.76 & $\mathrm{BDL}$ & 89.52 & 227.94 & 140.92 & 3.59 & 50.10 & 216.10 & 101.00 & 104.33 & 17.51 \\
Equine & 108.77 & 169.83 & $\mathrm{BDL}$ & 103.95 & 140.78 & 96.53 & 2.73 & 36.36 & 20.37 & 33.83 & 89.24 & 16.95 \\
Sm. Rum. & 90.11 & 244.38 & $\mathrm{BDL}$ & 95.69 & 153.32 & 110.22 & 3.47 & 24.08 & 43.07 & 37.03 & 259.91 & 16.30 \\
Dairy & 180.78 & 210.76 & 0.08 & 223.90 & 111.37 & 170.31 & 4.15 & 25.65 & 24.61 & 28.41 & 221.63 & 5.28 \\
\hline
\end{tabular}

BDL, below detection limit. Elements that were tested, however below detection limit in all dusts were cadmium, copper, nickel and lead; Sm. Rum., small ruminant; Bold, indicates highest concentration of element detected 
Table 7. Bacterial identification via media selection.

\begin{tabular}{|c|c|c|c|c|c|c|c|c|c|}
\hline Species & Centrimide & MYP & TSI & Oxford & S.M. & XLD & $\mathrm{RC}$ & $\mathrm{BP}$ & TSA \\
\hline Swine & - & + & + & + & - & - & + & + & + \\
\hline Sm. Rum. & - & + & + & + & - & - & + & + & + \\
\hline Dairy & - & + & + & + & - & - & + & + & + \\
\hline Poultry & - & + & + & + & + & - & + & + & + \\
\hline Equine & - & + & + & + & - & - & + & + & + \\
\hline
\end{tabular}

+ , bacterial colony/lawn growth observed; -, no bacterial colony/lawn growth observed

\section{DISCUSSION}

Dust collected from animal production facilities is extremely complex due to the nature of the facilities, species, feed and cleaning practices. Cleaning regimens coupled with ventilation are key factors in controlling air quality and dust accumulation. Dusts from animal husbandry units tended to contain higher levels of respirable particles $(<5 \mu \mathrm{m})$ regardless of housing or animal type. Inhalable dust particles are small enough to stay airborne. According to the ACGIH, the single most important factor influencing deposition along the respiratory tract is the "aerodynamic diameter" of a particle (ACGIH, 1999). Larger particles (i.e., 30-100 $\mu \mathrm{m})$ are inhalable and may deposit anywhere along the respiratory tract. Thoracic particles are smaller $(<10 \mu \mathrm{m}$ in diameter) and deposit with in tracheobronchial region, while respirable particles $(<2-5 \mu \mathrm{m}$; very small $<0.5 \mu \mathrm{m})$ can travel to the gas exchange/alveolar region of the lungs (ACGIH, 1999). Dust particles also referred to as Particulate Matter (PM) within poultry houses can range from ultrafine (PM2.5 and smaller) to PM2.5-10 with aerial dusts concentrations depending heavily on housing system type (Lai et al., 2012; Le Bouquin et al., 2013). This study reports higher levels of respirable and thoracic particles--within the PM10 and smaller range -than inhalable particles among all units tested.

Trace elements detected in this study were consistent with published reports for metals such as zinc, manganese and iron (Demmers et al., 2003). Higher levels of phosphorus and sulfur in the NCAT swine unit compared to other units is likely due to presence of feces; swine manure contains phosphorus and sulfur.

Respirable particles can enter systemic circulation, distribute throughout the body and elicit an immunological response owing to the increased number of sites nanoparticles have to react on cell membranes and a greater capacity to absorb and transport toxic substances (Garnett and Kallinteri, 2006). Ultra-fine particles $(<100 \mathrm{~nm})$ can elicit more severe inflammation than larger sized particles of the same material (Oberdorster et al., 2005).
Animal husbandry units can release a variety of particulates, including microbes, into the atmosphere. This study reported presumptive positives for bacteria based on 16S rDNA gene and growth detection. Bacteria and their components can potentiate respiratory symptoms and illnesses in agriculture workers. For instance, exposure to endotoxins-commonly referred to as lipopolysaccharides, are cell membrane component of gram negative bacteria-are potent inducers of neutrophilic airway inflammation and are a major risk factor for asthma among farmers (Charavaryamath and Singh, 2006), horses (Pirie et al., 2003) and sheep (Purdy et al., 2002). Interestingly, studies have shown that exposure to diverse microbial populations reduce incidences of allergies and asthma in children raised in rural and agricultural/farming areas compared to reference groups (Ege et al., 2011). Analysis of dust DNA samples-isolated from matress dust samples collected from the bedrooms of children living on farms and in rural and suburban communities--via PCR-Single-Strand Conformation Polymorphism (SSCP) gel electrophoresis and sequencing (Korthals et al., 2008) revealed inverse relationship between exposure to certain micriboal groups and asthma, hay fever and atopy (Ege et al., 2011; 2012). Bacterial species identified to be associated with this inverse relationship are Staphylococcus sp., Bacillus sp., Acinetobacter sp., Lactobacillus spp., Neisseria spp. and others (Ege et al., 2012). Two of these groups, Staphylococcus sp. and Bacillus sp., were identified in the present study and although not screed for directly, others are likely to be present as well.

There were no differences in the endotoxin levels among farm dust samples tested in the present study. Endotoxin levels depend on a variety of factors including animal species and numbers, feed types and production system styles. For example, higher dust, bacterial diversity and endotoxin levels were detected in cage-housed than floor-housed poultry operations (Just et al., 2011).

Reduced air quality in production facilities may contribute to respiratory dysfunction in farmers, farm 
workers, animals and farm visitors such as veterinarians (Poole et al., 2007). However, numerous studies document a 'protective effect' in children reared on farms against wheeze, asthma and atopy (Remes et al., 2005; Fuchs et al., 2012; Hulin and Annesi-Maesano, 2010; Ege et al., 2007; 2011; 2012). Other reports suggest exposure to endotoxins originating from domestic settings are associated with higher incidences of wheeze and asthma in school-age children, but not farm-borne endotoxins (Hulin and Annesi-Maesano, 2010). The potential protective effect of farm enviornments is less characterized in adults, but as summarized by Von Mutius and Radon (2008) few reports have suggested adult farmers are more protective from allergic diseases and hay fever compared to non-farming. It has also been shown that farm environments may protect from allergic rhinitis (Eriksson et al., 2010) and facilities with effiecient ventilation systems further reduce effects of animal production environments (Skorska et al., 2007). Thus studies characterizing basic biology and clinical outcome of farm exposures in adults may resolve.

Agriculture workers manifest a complex overlapping group of disorders including acute bronchitis, chronic bronchitis, asthma, interstitial disease and acute lung injury (May et al., 2012). Wyatt et al. (2008) showed that hog barn dust can impact the normal stimulation of cilia in bovine ciliated cells. This can lead to defective mucociliary clearance and particulates not being excreted out of the airway efficiently. Poole et al. (2009), showed exposure to organic dust can modulate differentiation, maturation and phagocytic activity of dendritic cells and peripheral blood lymphocytes in vitro; and time of exposure is important for driving expression of cell surface markers. Hog barn dust stimulates secretion of cytokines Interleukin (IL) -8 and IL-6 by human bronchial epithelial cells in vitro (Poole et al., 2007; 2008). This potentially explains why some persons exposed to agriculture dusts manifest neutrophilia; IL-8 is a recruiter of neutrophils.

Two important limitations of the present study are that analysis was performed on settled dust and a modest number of farms were sampled. It is possible that the results would differ for dusts collected using a different sampling method. Reports summarizing dust characterization and exposure studies have used a myriad of sample collection strategies including static cloths (Ege et al., 2012), air sampling (Oppliger et al., 2008) and brush collection (Wyatt et al., 2008). However, an understanding of settled dust particles would provide insight into the nature and interactions of larger dust constituents which are more likely to accumulate and persist within animal production housing. It is important to understand both dust categories, that is, larger and smaller dust particles.

With regard to the number of units sampled, husbandry dust characterization studies depend heavily on access to animal production facilities. With the exception of swine and poultry, two-three husbandry units per species were analyzed in the present study. Ultimately, there is a need for more studies of this nature to fully understand agricultural dust exposures.

\section{CONCLUSION}

Agricultural dust in animal production buildings consists of a complex mixture of grain/feed particles, microbial products (endotoxin), a variety of gases, metals and other components. Chronic inhalation of such animal production dust has been associated with occupational respiratory symptoms in farmers and workers; lesser is known about potential effects on animals. The present study found more respirable versus inhalable particles in all livestock unit dust samples and provides some preliminary evidence in possible differences for dust particle sizes and bacterial species among livestock units that need to be more fully explored. Important next steps should characterize exposures to microbial species and their products within animal unit dusts.

\section{ACKNOWLEDGEMENT}

We thank Shurrita Davis, Damian King, Crystal Kyle and Chantal Armston for technical assistance. We acknowledge Christina A. Miller, Research Apprenticeship Program intern, for technical assistance. We thank Leon Moses for helpful discussions. A portion of a dissertation by the first author, C.G. This study was supported by United States Department of Agriculture - National Institute of Food and Agriculture Grant \# NC.X-255-5-11-120-1 (J.T.W.).

\section{REFERENCES}

ACGIH, 1999. Particle Size-Selective Sampling for Health-Related Aerosols. Air Sampling Procedures Committee, ACGIH, Cincinnati, OH, USA. 
Becker, K., R. Roth and G. Peters, 1998. Rapid and specific detection of toxigenic Staphylococcus aureus: Use of two multiplex PCR enzyme immunoassaysfor amplification and hybridization of staphylococcal enterotoxingenes, exfoliative toxin genes andtoxic shock syndrome toxin 1 gene. J. Clin. Microbiol., 36: 2548-2553.

Charavaryamath, C. and B. Singh, 2006. Pulmonary effects of exposure to pig barn air. J. Occup. Med. Toxicol., 1: 10-10. DOI: 10.1186/1745-6673-1-10

Chmielowiec-Korzeniowska, A., 2009. The concentration of volatile organic compounds (VOCs) in pig farm air. Ann. Agric. Environ Med., 16: $249-56$.

Demmers, T.G.M., C.M. Wathes, P.A. Richards, N. Teer and L.L. Taylor et al., 2003. A facility for controlled exposure of pigs to airborne dusts and gases. Biosyst. Eng., 84: 217-230. DOI: 10.1016/S15375110(02)00243-X

Donham, K.J., D. Cumro and S. Reynolds, 2002. Synergistic effects of dust and ammonia on the occupational health effects of poultry production workers. J. Agromed., 8: 57-76. DOI: 10.1300/J096v08n02_09

Ege M.J., R. Frei, C. Bieli, D. Schram-Bijkerk and M. Waser et al., 2007. Not all farming environments protect against the development of asthma and wheeze in children. J. Allergy Clin. Immunol., 119: 1140-1147. DOI: 10.1016/j.jaci.2007.01.037

Ege, M.J., M. Mayer, K. Schwaiger, J. Mattes and G. Pershagen et al., 2012. Environmental bacteria and childhood asthma. Allergy, 67: 1565-1571. DOI: 10.1111/all.12028

Ege, M.J., M. Mayer, A.C. Normand, J. Genuneit and W.O. Cookson et al., 2011. Exposure to environmental microorganisms and childhood asthma. N. Engl. J. Med., 364: 701-709. DOI: 10.1056/NEJMoa1007302

Eriksson, J., L. Ekerljung, J. Lotvall, T. Pullerits and G. Wennergren et al., 2010. Growing up on a farm leads to lifelong protection against allergic rhinitis. Allergy, 65: 1397-1403. DOI: 10.1111/j.13989995.2010.02397

FOA, 2012. Animal production and health: Sources of meat. Food and Agriculture Organization of the United Nations.

Fuchs, O., J. Genuneit, P. Latzin, G. Buchele and E. Horak et al., 2012. Farming environments and childhood atopy, wheeze, lung function and exhaled nitric oxide. J. Allergy Clin. Immunol., 130: 382388. DOI: 10.1016/j.jaci.2012.04.049
Garnett, M.C. and P. Kallineteri, 2006. Nanomedicines and nanotoxicology: S ome physiological principles. Occup. Med., 56: 307-311. DOI: 10.1093/occmed/kq1052

Hamon, L., Y. Andres and E. Dumont, 2012. Aerial pollutants in swine buildings: A review of their characterization and methods to reduce them. Environ. Sci. Technol., 46: 12287-12301. DOI: 10.1021/es3025758.

Heuer, H., M. Krsek, P. Baker, K. Smalla and E.M. Wellington, 1997. Analysis of actinomycete communities by specific amplification of genes encoding 16S rRNA and gel-electrophoretic separation in denaturing gradients. Applied Environ. Microbiol., 63: 3233-3241.

Hulin M. and I. Annesi-Maesano, 2010. Allergic diseases in children and farming environment. Rev. Mal. Respir., 27: 1195-1220. DOI: 10.1016/j.rmr.2010.10.002

Just, N., S. Kirychuk, Y. Gilbert, V. Letourneau and M. Veillette et al., 2011. Bacterial diversity characterization of bioaerosols from cage-housed and floor-housed poultry operations. Environ. Res., 111: 492-498. DOI: 10.1016/j.envres.2011.01.009

Korthals, M., M.J. Ege, C.C. Tebbe, E. von Mutius and J. Bauer, 2008. Application of PCR-SSCP for molecular epidemiological studies on the exposure of farm children to bacteria in environmental dust. J. Microbiol. Methods, 73: 49-56. DOI: 10.1016/j.mimet.2008.01.010

Kumari, M., B.E. Myagmarjav, B. Prasad and M. Choudhary, 2013. Identification and characterization of antibiotic-producing actinomycetes isolates. Am. J. Microbiol., 4: 24-31. DOI: 10.3844/ajmsp.2013.24.31

Lai, H.T., M.G. Nieuwland, A.J. Aarnink, B. Kemp and H.K. Parmentier, 2012. Effects of 2 size classes of intratracheally administered airborne dust particles on primary and secondary specific antibody responses and body weight gain of broilers: A pilot study on the effects of naturally occurring dust. Poult. Sci., 91: 604-615. DOI: 10.3382/ps.201101829.

Le Bouquin, S., A. Huneau-Salaun, D. Huonnic, L. Balaine and S. Martin et al., 2013. Aerial dust concentration in cage-housed, floor-housed and aviary facilities for laying hens. Poult. Sci., 92: 2827-2833. DOI: 10.3382/ps.2013-03032 
Lee, S.A., A. Adhikari, S.A. Grinshpun, R. McKay and R. Shukla et al., 2006. Personal exposure to airborne dust and microorganism in agricultural environments. J. Occup. Environ. Hyg., 3: 118-130. DOI: $10.1080 / 15459620500524607$

Lioy, P.J., C.P. Weisel, J.R. Millette, S. Eisenreich and D. Vallero et al., 2002. Characterization of the dust/smoke aerosol that settled east of the World Trade Center (WTC) in lower Manhattan after the collapse of the WTC11 September 2001. Environ. Health Perspect., 110: 703-714. DOI: 10.1289\%2Fehp.02110703

May, S., D.J. Romberger and J.A. Poole, 2012. Respiratory health effects of large animal farming environments. J. Toxicol. Environ. Health B Crit. Rev., 15: 524-541. DOI: 10.1080/10937404.2012.744288

McDaniels, A.E., E.W. Rice, A.L. Reyes, C.H. Johnson and R.A. Haugland et al., 1996. Conformational identification of Escherichia coli, a comparison of genotypic andphenotypic assays for glutamate decarboxylase and $\beta$-D-glucuronidase. Applied Environ. Microbiol., 62: 3350-3354.

Mitloehner, F.M. and M.A. Calvo, 2008. Worker health and safety in concentrated animal feeding operations. J. Agric. Saf. Health, 14: 163-187. DOI: $10.13031 \% 2$ F2013.24349

O'Shaughnessy, P.T., K.J. Donham, T.M. Peters, C. Taylor and R. Altmaier et al., 2010. A task-specific assessment of swine worker exposure to airborne dust. J. Occup. Environ. Hyg., 7: 7-13. DOI: 10.1080/15459620903327970

Oberdorster, G., E. Oberdorster and J. Oberdorster, 2005. Nanotoxicology: An emerging discipline evolving from studies of ultrafine particles. Environ. Health Perspect., 113: 823-839. DOI: 10.1289/ehp.7339

Oppliger, A., N. Charriere, P.O. Droz and T. Rinsoz, 2008. Exposure to bioaerosols in poultry houses at different stages of fattening; use of real-time PCR for airborne bacterial quantification. Ann. Occup. Hyg., 52: 405-412. DOI: 10.1093/annhyg/men021

Pirie, R.S., D.D.S. Collie, P.M. Dixon and B.C. McGorum, 2003. Inhaled endotoxin and organic dust particulates have synergistic proinflammtory effects in equine heaves (organic dust-induced asthma). Clin. Exp. Allergy, 33: 676-683. DOI: 10.1046/j.1365-2222.2003.01640.x
Plummer, L.E., K.E. Pinkerton, S. Reynolds, S. Meschke and F. Mitloehner et al., 2009. Aerosols in the agricultural setting. J. Agromed., 14: 413-416. DOI: 10.1080/10599240903260527

Poole, J.A., G.M. Thiele, N.E. Alexis, A.M. Burrell and C. Parks et al., 2009. Organic dust exposure alters monocyte-derived dendritic cell differentiation and maturation. Am. J. Physiol. Lung Cell Mol. Physiol., 297: L767-L776. DOI: 10.1152/ajplung.00107.2009

Poole, J.A., N.E. Alexis, C. Parks, A.K. MacInnes and M.J. Gentry-Nielsen et al., 2008. Repetitive organic dust exposure in vitro impairs macrophage differentiation and function. J. Allergy Clin. Immunol., 122: 375-382. DOI: 10.1016/j.jaci.2008.05.023.

Poole, J.A., T.A. Wyatt, S.G. Von Essen, J. Hevert and C. Parks et al., 2007. Repeat organic dust exposureinduced monocyte inflammation is associated with protein kinase C activity. J. Allergy Clin. Immunol., 120: 366-373. DOI: 10.1016/j.jaci.2007.04.033

Purdy, C.W., D.C. Straus, N. Chirase, D.B. Parker and J.R. Ayers et al., 2002. Effects of aerosolized feedyard dust that contains natural endotoxins on adult sheep. Am. J. Vet. Res., 63: 28-35. DOI: 10.2460\%2FAJVR.2002.63.28

Rahn, K.S., S.A. De Grandis, R.C. Clarke, S.A. Mcewen and J.E. Galan et al., 1992. Amplification of an invA gene sequence of Salmonella enterica bypolymerase chain reaction as a specific method of detection of Salmonella. Mol. Cell Probes, 6: 271279. DOI: $10.1016 / 0890-8508(92) 90002-F$

Remes, S.T., H.O. Koskela, K. Iivanainen and J. Pekkanen, 2005. Allergen-specific sensitization in asthma and allergic diseases in children: The study on farmers' and non-farmers' children. Clin. Exp. Allergy, 35: 160-166. DOI: 10.1111\%2Fj.13652222.2005.02172.x

Sacchi, C.T., A.M. Whitney, L.W. Mayer, R. Morey and A. Steigerwalt et al., 2002. Sequencingof 16S rRNA gene: A rapid tool for identification of Bacillusanthracis. Emerg. Infect. Dis., 8: 1117-1123. DOI: 10.3201/eid0810.020391

Sasaki, Y., N. Takikawa, A. Kojima, M. Norimatsu and S. Suzuki et al., 2001. Phylogenetic positions of clostridium novyi and clostridium haemolyticum based on 16s rDNA sequences. Int. J. Syst. Evol. Microbiol., 51: 901-904. DOI: 10.1099/0020771351-3-901 
Skorska C., B. B. Mackiewicz, M. Golec, G. Cholewa, A. Chmielowiec-Korzeniowska and J. Dutkiewicz, 2007. Health effects of exposure to organic dust in workers of a modern hatchery. Ann. Agric. Environ. Med., 14: 341-345.

Viegas, S., V.M. Faisca, H. Dias, A. Clerigo and E. Carolino et al., 2013. Occupational exposure to poultry dust and effects on the respiratory system in workers. J. Toxicol. Environ. Health A., 76: 230239. DOI: 10.1080/15287394.2013.757199.

Von Mutius, E. and K. Radon, 2008. Living on a farm: Impact on asthma induction and clinical course. Immunol. Allergy Clin. North Am., 28: 631-647. DOI: 10.1016/j.iac.2008.03.010

WHO, 1999. Hazard prevention and control in the work environment: Airborne dust. World Health Organization, Geneva.
Widmer, F., R.J. Seidler, P.M. Gillevet, L.S. Watrud and G.D. Di Giovanni, 1998. A highly selective PCR protocol for detecting 16S rRNA genes of the genus Pseudomonas (sensu stricto) in environmental samples. Applied Environ. Microbiol., 64: 25452553.

Wu, S.J., A. Chan and C.I. Kado, 2004. Detection of PCR amplicons from bacterial pathogens using microsphere agglutination. J. Microbiol. Methods, 56: 395-400. DOI: 10.1016/j.mimet.2003.11.005

Wyatt, T.A., J.H. Sisson, S.G. Von Essen, J.A. Poole and D.J. Romberger, 2008. Exposure to hog barn dust alters airway epithelial ciliary beating. Eur. Respir. J., 31: 1249-1255. DOI: $10.1183 / 09031936.00015007$ 